\title{
Facets in an Analytico-Synthetic Classification and Their Role in Subject Retrieval
}

\author{
Victoria Frâncu \\ $\mathrm{PhD}$ \\ Romanian Library Association \\ E-mail v_francu@yahoo.com
}

\begin{abstract}
The limitations of the enumerative nature of the Universal Decimal Classification (UDC) are compensated by the existence of the auxiliary tables, also known as facets, which provide flexibility to and enhance the expressiveness of the classification as a whole. Their use makes new notations possible through synthesis, avoiding as a result further subdividing and enumeration of concepts. This way, new compound numbers are created with a direct impact on the flexibility of the classificatory structure. The paper aims to focus on the UDC auxiliary tables and their contribution to improved expressiveness of the subjects represented by the UDC main class numbers. Our purpose is to demonstrate that despite the limitations of an analytico-synthetic classification system designed more than one hundred years ago, successive developments of the scheme along with the consistent updating of its functionalities enables it to be successfully used in modern information retrieval systems both from bibliographic and non-bibliographic domain. The impact of these features on subject retrieval are explored in the paper.
\end{abstract}

Keywords: Universal Decimal Classification; auxiliary tables; analytico-synthetic classifications; faceted classifications; information retrieval

\section{Introduction}

One of the meanings of the word facet in Cambridge English Dictionary is "one part of a subject, situation etc. that has many parts". In this meaning the word is used in library and information science to denote parts of a classification scheme which can be combined in order to express a compound subject. The theory and principles of faceted classification were developed, as commonly known, by Ranganathan (1965) and the Classification Research Group (CRG) in the second half of the $20^{\text {th }}$ century. This came about as a reaction to the difficulties of traditional enumerative classification systems such as Dewey Decimal Classification and Library of Congress Classification, to express complex subjects. The Colon Classification devised by Ranganathan and based on his own theory of facet analysis is a landmark in the history of library classification through its flexibility and its capability of synthesis, still influencing to a great extent the library world (Vlădescu 1965). Important thesauri and subject heading lists which are extensively used nowadays like Medical Subject Headings, Library of Congress Subject Headings or Art and Architecture Thesaurus, are based on the facet theory.

The limitations of the enumerative nature of the Universal Decimal Classification (UDC) are compensated by the existence of the auxiliary tables, also known as facets, which provide flexibility and adds expressiveness to the classification as a whole. Their use make new notations possible through synthesis, avoiding thus further subdividing and enumeration of concepts. This way new compound numbers are created with a direct impact on the flexibility of the classificatory structure. This paper aims to focus on the UDC auxiliary tables and the way they contribute to improved expressiveness of the subjects represented by the UDC main class numbers.

At the same time, our purpose is to demonstrate that despite the limitations of an analytico-

Revista Română de Biblioteconomie şi Ştiința Informării = Romanian Journal of Library and Information Science ISSN 2559-5490, ISSN-L 1841-1940 • Volume 14 Issue 32018 pp. 64-74 https://doi.org/10.26660/rrbsi.2018.14.3.64

This work is licensed under a Creative Commons Attribution-NonCommercial-NoDerivatives 4.0 International License 
synthetic classification designed more than one hundred years ago, successive developments of the scheme along with consistent updating of its functionalities enabled it to be successfully used in modern information retrieval systems. As class numbers tend to be avoided by library users, librarians are facing new missions in order to tackle the subject access problem. Librarians have the mission of an intermediary element between the indexer and the user and also between the user and his/her information needs.

Current information seeking behavior generates an important change in subject representation intended to meet the user information needs. While users want fast retrieval of most relevant information without much regard for the information retrieval expertise, dealing with natural language words for subject access makes procedures quite straightforward. Furthermore, subject clouds enable expansion of the subject areas through navigation and an interface for mobile devices is an efficient response to the forthcoming user demands.

\section{Some details on the use of facets in post-coordinated search}

On the minimal requirement of the correct usage of the classification rules, a numerical expression like this: $811.135 .1243(075.8)=14$ can be translated as search query into: "Romanian as a second language - university textbook for Greek speakers".

In the given example the complex UDC notation consists of one main class number and several auxiliaries (one special and two common) which can be used in turns with la large variety of other main numbers for similar concepts. The form and language common auxiliaries (or facets) can be used throughout the entire classification to represent characteristics regarding the inner or outer form of the document and - on condition of relevance - the language in which it is written. These two, along with the place and time facets, particularly meaningful for documents on geography and history, are sine qua non devices for accurate representation of subject-related concepts in documents and they are equally meaningful in information retrieval. The common auxiliary of language, or language facet will retrieve all documents written in Greek, in our case, when used as search query element. Likewise, the common auxiliary of form, (075.8) will retrieve at the end of a post-coordinate search, all the university textbooks in the information system.

There are two types of auxiliaries in the structure of the UDC tables: common auxiliaries and special auxiliaries. The common auxiliaries, used with the same meaning irrespective of the main class they are attached to indicate: language, form, place, time, general characteristics. They modify by special features the subject expressed by the main class number:

$730(450)$

75(498)(084)

$323.15(=112.2)(498.4)$ " 19 " Germans as ethnic minorities in Transylvania in the $20^{\text {th }}$ century

Unlike the first category, the special auxiliaries are limited in their scope, and each series is used to denote recurrent concepts in that part of the main tables for which it is designed, or in particular other sections where specifically indicated. For example, the special auxiliary subdivision .02 modifies differently the meaning of specific main classes as follows:

53.02

54.02

82.02
General laws and phenomena (Physics)

Composition. Structure. Isotopes (Chemistry)

Literary schools, trends, movements (Literature)

Older and more recent UDC developments such as: AUDACIOUS (Freeman \& Atherton 1968), GERHARD (Moller et al. 1999), ETHICS and NEBIS reveal the deep interest in reusing classification data from library catalogues by including them in subject authority files (Figure 1). The example below illustrates an authority record based on an auxiliary of ethnic grouping, which is actually the auxiliary (facet) of language included between round parentheses with the role of facet indicators. 


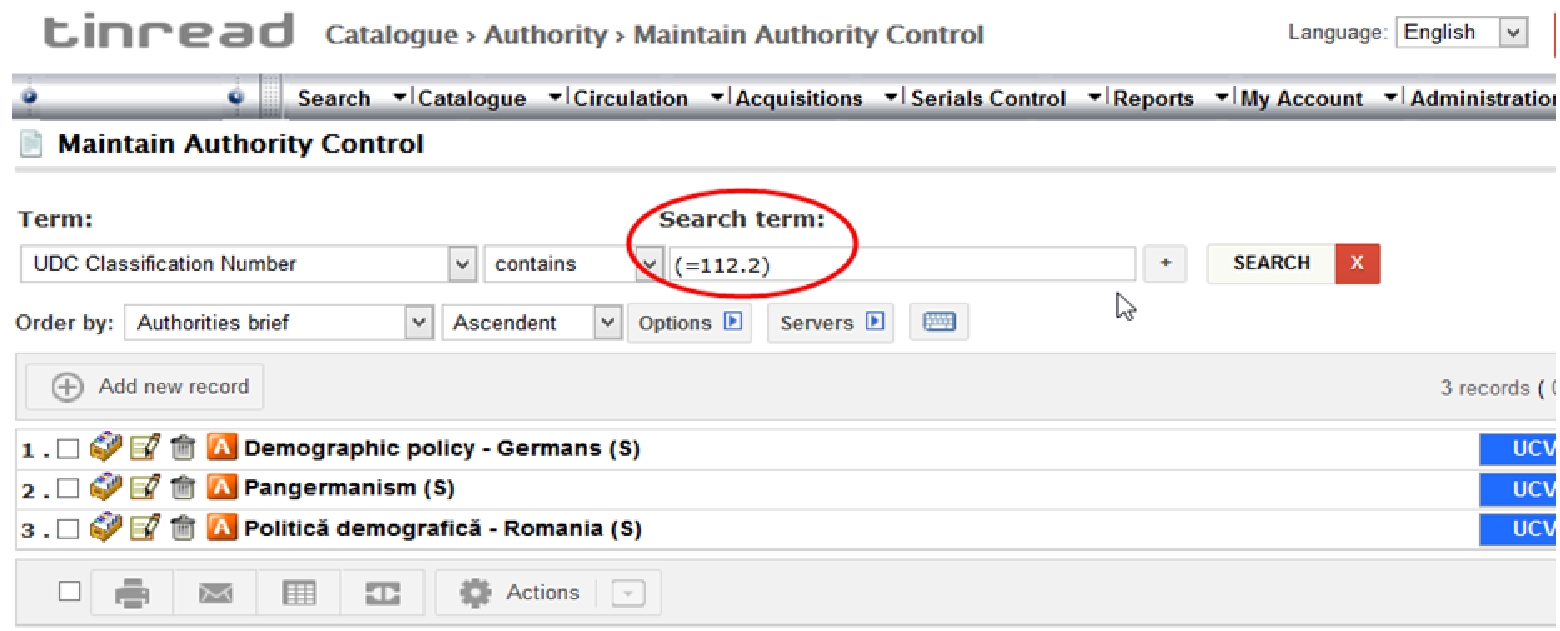

Figure 1. Common auxiliary of ethnic grouping as search element in an authority file

Critical issues of implementation will arise in case of common auxiliaries not being appropriately parsed, or rather not correctly marked, according to the standard facet indicators. For example, a search query for -02 from Table $1 \mathrm{k}$-Common auxiliaries of properties can lead to a wrong interpretation for the system and consequently give false results, being erroneously taken for "- 02 " from Table 1g-Common auxiliaries of time and thus including documents about the $3^{\text {rd }}$ century $\mathrm{BC}$ in the retrieved set. In such a case, a convention has to be decided on a different symbol to be used as facet indicator in order to avoid confusion.

\section{Common auxiliaries are not UDC numbers of secondary degree}

A brief reminder of the common auxiliary tables in the UDC accompanied by a number of examples of use from real library catalogues will help us understand their importance in delineating particular aspects of the subjects which add value to the relevance of the documents retrieved.

The conversion process from numerical expressions to natural language terms is assisted by what Drake calls in the Encyclopedia of Library and Information Science the auxiliaries of addition, extension and relation (Drake 2003 p. 2868). In the UDC Online (http://www.udc-hub.com/ search.php) the common auxiliaries are grouped in the following categories:

Table la - Connecting symbols. Coordination. Extension (+ or /) - used to join separate or consecutive subjects together;

Table $1 b$ - Relating symbols (:, :: or [])-used to link and cluster UDC numbers in order to denote further concepts.

The symbols of both types of auxiliaries have a role in parsing complex or compound notations in their meaningful component parts.

Table 1c - Common auxiliaries of language are the source of subdivision of Class 811 Languages and Class 821 - Literatures of individual languages and language families and represent the meaningful elements of Table $1 \mathrm{f}$ for auxiliaries of ethnic grouping.

Table 1d-Common auxiliaries of form denote the form or presentation of documents. Mention should be made here on the difference between the inner and outer form. Berwick Sayers (1957) explains that they denote "on the one hand the internal point of view or approach to the subject and, on the other hand, the physical arrangement or form of the material".

Table 1e - Common auxiliaries of place - used to indicate the geographical range, space or spatial aspects of subjects and are considered as primary facet for Class 913 - Regional geography and Class 94 - History.

Table If - Common auxiliaries of human ancestry, ethnic grouping and nationality - denote the 
nationality or ethnic aspect of the subject represented by the main class.

Table $1 g$ - Common auxiliaries of time - denote a particular date, point of time or ranges of time; as the "+" and "-" signs are used to denote the pre-Christian and Christian era, they should be treated cautiously in order to avoid confusion in the conversion process.

Table $1 k$ - Common auxiliaries of general characteristics - has 1591 subdivisions grouped in 4 categories:

-02 Common auxiliaries of properties (831 subdivisions)

-03 Common auxiliaries of materials (152 subdivisions)

-04 Common auxiliaries of relation, processes and operations (338 subdivisions)

-05 Common auxiliaries of persons and personal characteristics (270 subdivisions)

Table $1 \mathrm{~h}$ - Subject specification by notations from non-UDC sources and alphabetic extensionmay be used to increase the specificity of a UDC class mark.

The following set of Google search results comes from a query using the compound UDC number 323.28-055.2, as search expression. The meaning of the main UDC number, according to the UDC Online, is Political persecution. Terrorism and that of the common auxiliary number attached to it is Women.

1. Femei kamikaze - terorism la genul feminin / Maria Cristina Chiru, Irena Chiru . - Bucureşti :

Editura Top Form, 2006

323.28-055.2(100) international terrorism - women

Biblioteca Universității Danubius - Galați (http://bit.ly/rrbsi32018a)

2. Krvavé jahody / Jiří S. Kupka. - Praha : Mladáfronta, 2008

323.28-055.2 (437)(47+57) women political prisoners - Czechoslovakia - Soviet Union

National Library of the Czech Republic (Portaro katalog knihovny - http://bit.ly/rrbsi32018b)

3. Romanian Women in Communist Prisons 1945-1989 / Graţian Cormoş . - Cluj-Napoca :

Argonaut, 2010

323.28-055.2(498)

Biblioteca Naţională a Republicii Moldova (http://bit.ly/rrbsi32018c)

4. Ti scrivo da sotto le bombe : pagine di rabbia e di speranza delle donne contro la guerra e le violenze nella ex Yugoslavia / a cura di: Monica Lanfranco, Cristina Papa . - 2-a ed. -Genova : Erga, 1999

$323.28(=18: 497.115) 323.28-055.2(=18: 497.115)$

Genocidi

Gra

Jugosllavi

Kosovë

Gadishulli Ballkanik

Biblioteka Kombëtare e Shqipërisë (http://bit.ly/rrbsi32018d)

5. Women, gender and terrorism / ed. by Laura Sjoberg and Caron E. Gentry. - Athens: University of Georgia Press, c. 2011

323.28-055.2

Lillehammer University College Library (http://bit.ly/rrbsi32018e)

6. Ženske in terorizem :vlogažensk $\mathbf{v}$ terorističnihorganizacijah : diplomskodelo / NikaHusar. Ljubljana, 2012

323.28-055.2(043.2) terorizem / ženske / teroristke / diplomskenaloge

Slovenian Virtual Catalog (http://bit.ly/rrbsi32018f)

In all, except for the fifth example, one or more common auxiliaries are added to the initial compound UDC expression and only two out of the six records resulting from the search do not have descriptors for subject representation. The most complex of the set of retrieved documents is the fourth which holds, in addition to the initial common auxiliary of person i.e. -055.2, a common auxiliary of ethnic grouping, i.e. $(=18)$ Albanians and a common auxiliary of place, i.e. (497.115) 
Province of Kosovo. The examples provided demonstrate the great variety of concepts capable to be represented by common auxiliaries and how they can enrich the relevance of the search results through synthesis. Other than this, on condition of browsing and navigation availability, these results can be significantly enhanced.

\section{Classification authority data and their implementation}

The multiple qualities of the UDC as knowledge organizer and its availability in electronic form (the UDC Master Reference File) empowered its role as "underlying knowledge structure that provides systematic subject organization and thus complements the search using natural language terms" (Slavic 2004). Evolving from Otlet's representation of human knowledge and denoting his attempt to provide a complete "image of the world" (Ducheyne 2009), the UDC has all the necessary equipment to be effectively used in subject access. Facets and facet indicators have an important role in that.

The implementation of classification authority data in library catalogues conveys consistency in indexing and imposes control over the indexing terms. As earlier said, there are many examples of information systems which include classification data in authority files. A very good example of such development is NEBIS, a system that has been used at ETH Zurich since the early 1980s. At the moment, NEBIS (https://www.nebis.ch/en/frontpage) is a knowledge system which includes 140 institutions.

The pre-coordinated keyword chains in three languages (German, English and French) together with the corresponding UDC numbers are stored in a subject index (Hug \& Noethiger 1991). Along with these terms, some synonyms and their logical context (broader terms, narrower terms and related terms) are also incorporated. The Boolean operators such as AND, OR and NOT can enlarge or restrict the result. At the moment of information retrieval the post-coordinated descriptors are used and this happens particularly when the search query is formulated. The detailed UDC-based subject index obviously contains terms mapped from the auxiliary numbers and the richness of the vocabulary elements in three languages provides higher relevance and more flexibility to the information acquired as search result. As we learn from the NEBIS website, for specific queries limited to the UDC index, the ESS11 database is available. Searches can be made either by UDC numbers or by terms in their captions.

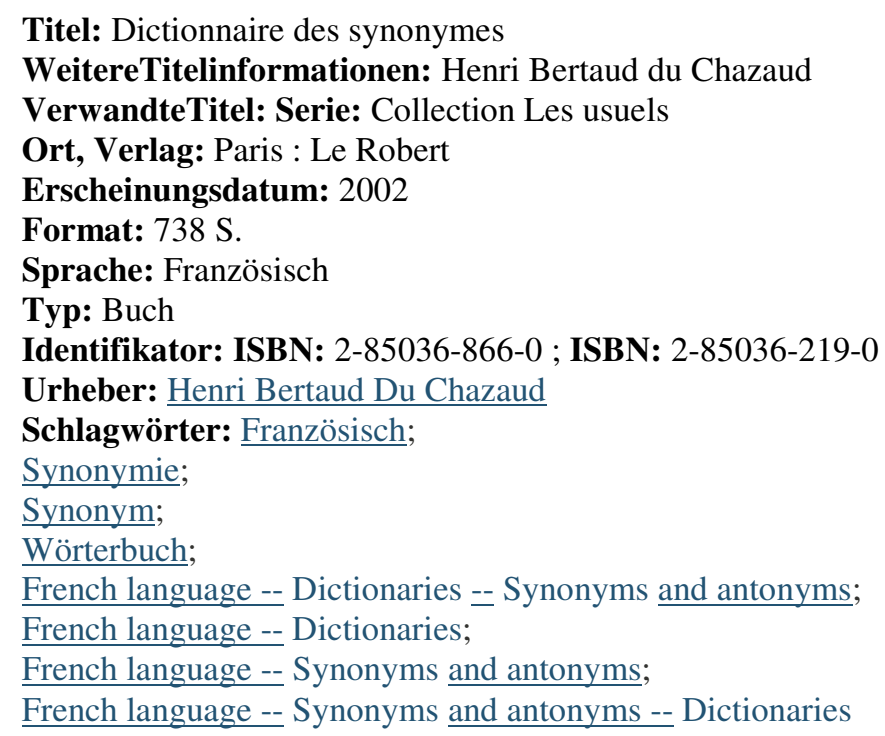

Figure 2. Search result in ESS11 database of NEBIS, starting from a UDC number 
A rather comparable approach is used by a Romanian-made information system called TinREAD (The Information Navigator for Readers). The subject retrieval part of TinREAD integrated system was designed to handle the assignment of verbal index terms mapped to classification numbers in bibliographic records by means of two types of authority files: subject headings and UDC (Frâncu\&Dediu 2015). Three connected entities form the minimum necessary conditions for this objective: the bibliographic record, the subject authority record and the UDC notation (which is either simple or compound). Once implemented in the information retrieval system, the subject authority file provides multiple access points to document subjects and enables semantic search expansion (Figures 3, 4).

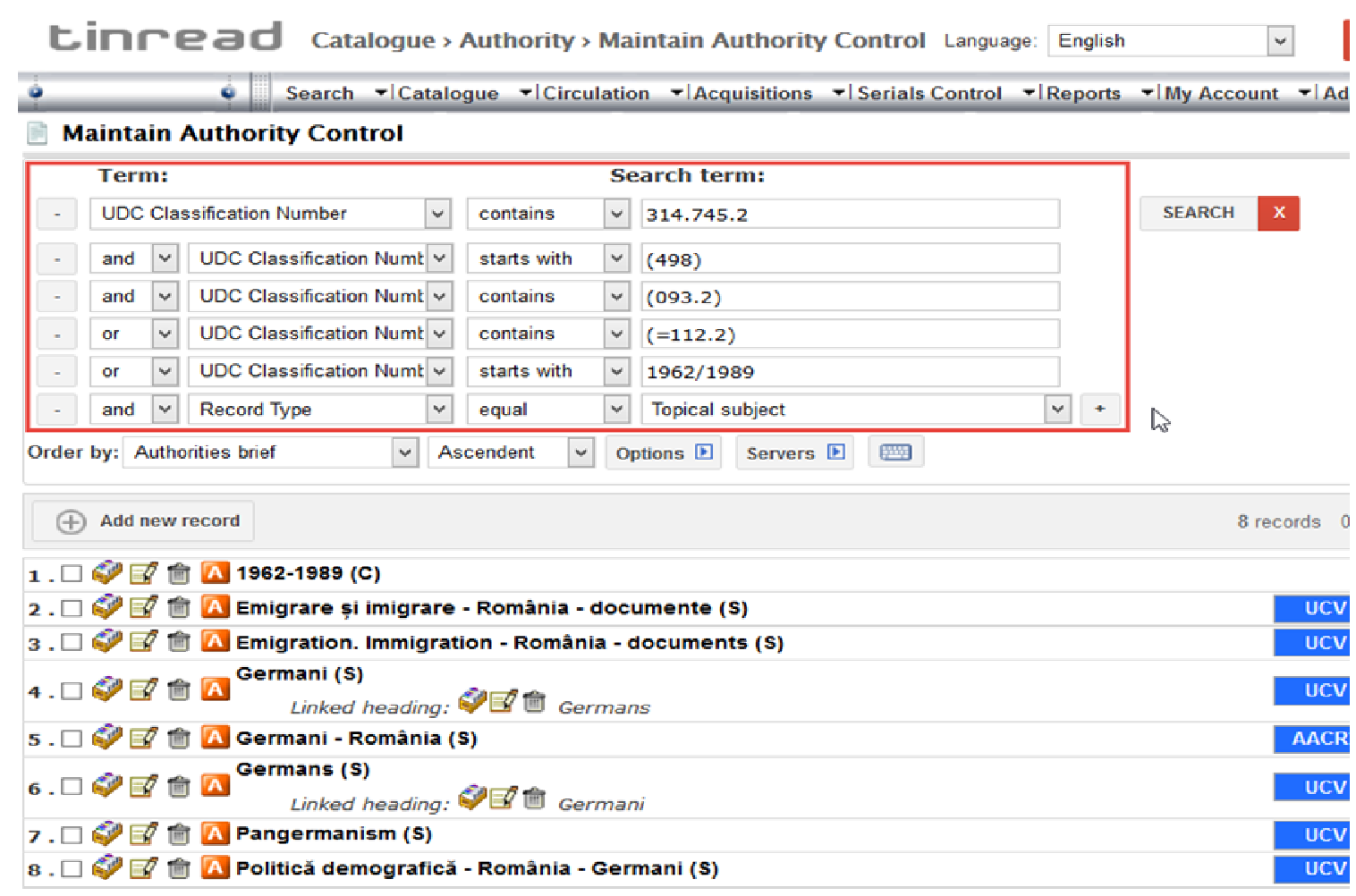

Figure 3. Authority record for a compound UDC number including four kinds of facets

In TinREAD separate authority files are linked with bibliographic records in order to improve the quality and consistency of indexing. Subject-oriented data is held in fields 6xx for classification and in fields 9xx for subject headings or thesaurus terms, as defined by the MARC bibliographic format. As long as a UDC number is assigned to a 675 field of a bibliographic record, the system automatically provides its corresponding subject heading in a 606 field (Frâncu \& Dediu 2015 p. 130). The reverse holds also true, any descriptor employed for indexing in a 606 is automatically mapped with a classification notation.

According to the UNIMARC-A format, each authority record contains mandatory fields like: 250 for the Romanian descriptor, 675 for the UDC number, simple or compound, 750 linking fields for possible multi-language (or multi-script) variants or equivalent subject terms from other vocabularies if accessible, and for the semantic context, as many repeatable 9xx fields as available for broader terms, narrower terms and related terms. All of these have separate authority records, therefore become access points to subjects in their own right.

Compound UDC numbers including various facets are treated so that each of their contributing elements has its own representation in appropriate subject terms, as demonstrated in the upper part of the example illustrated in Figure 3. The four different facets (for ethnic grouping, place, time and form) attached to the main UDC number provide dependability to the subject representation. Each of these facets can be further used as access points. 


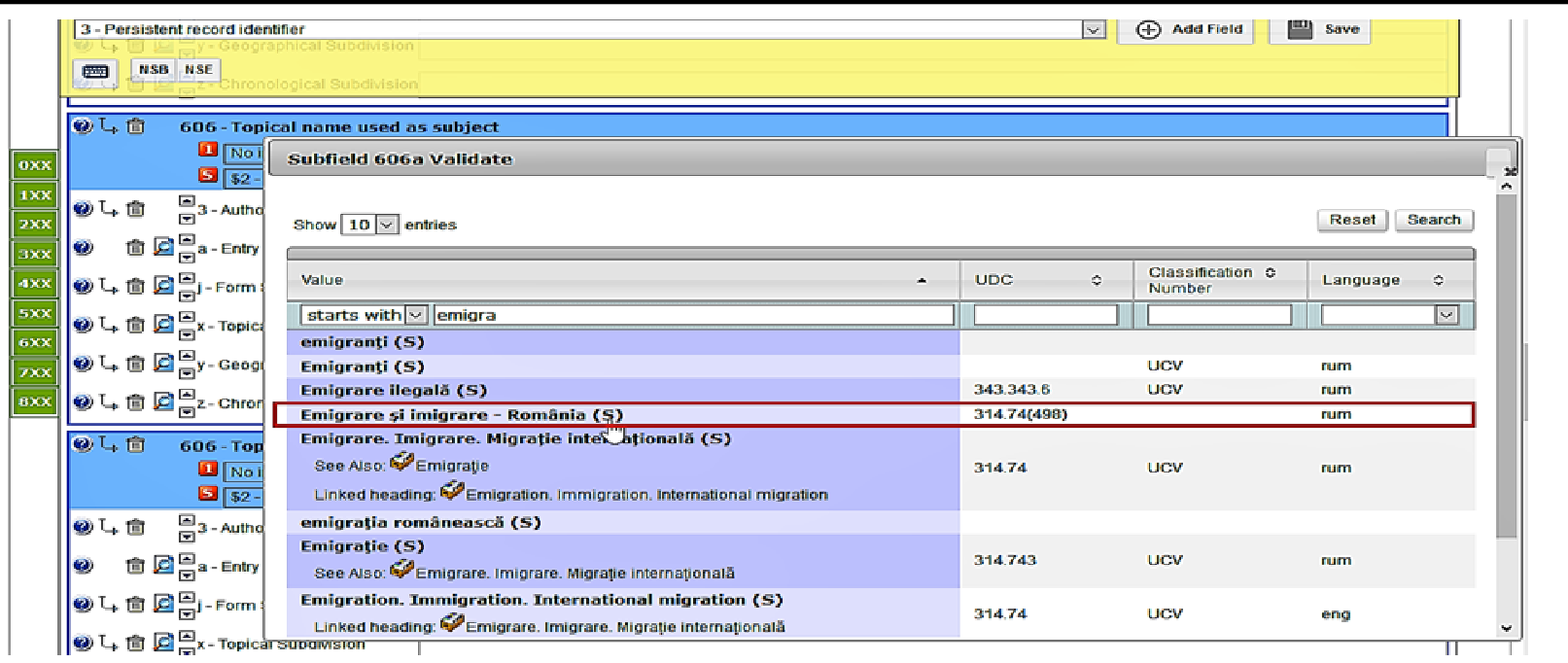

Figure 4. Selection of appropriate subject heading and UDC notation

An extra benefit of the system for enlarging the subject area is the interactive navigation option provided by subject clouds (Figure 5). A search for the term Semantics (Semantică in Romanian) as descriptor, will retrieve in a TinREAD library catalogue a total sum of 138 documents, in 8 languages, of which 66 are in Romanian, 31 in English and 25 in French, plus others in smaller numbers. Special remark should be made on the structure of the UDC notation for this concept, i.e. $81 ` 37$, which is derived from Class 81 through synthesis, by addition of the special auxiliary `37 to the main number. This special auxiliary can be successively added to express the same concept, i.e. Semantics, to any particular language scheduled in Table 1c - Common auxiliaries of language. The main numbers for languages themselves are the result of synthesis between the main class number 81 and the language facets.

We can then have:

811.135.1`37 - Romanian language - Semantics

811.11137 - English language - Semantics

811.112.2`37 - German language - Semantics

and so on.

Grup verbal Theory of translation Semantics Lingvistică comparată Limba latină Biblia Verbes

Etimologie Literatură engleză Literatură română Limbaj literar Filosofie Sociologia comunicării Phraseologie

Semantică Antonyms Lingvistică structurală Limba spaniolă Phonology Semiotics Anthroponymy Lingvistică aplicată Onomastică Critică literară Analiza discursului Limbaj juridic Antonime Limba rusă Gramatică comparată Cognitive science Dialectology Latin Toponimie Structuralism Limba greacă Grammaire générative frazeologie Sociolingvistică Limbaj militar Barbu, Ion Complementele propoziției Arabic Limba greacă clasică Gramatică generativă

Figure 5. Sample of subject cloud for Semantics as descriptor

\section{Syntax rules and synthesis for faceted approach}

In the Semantics example above the rule of building compounds by synthesis can be easily noticed. Likewise, the rule of building numbers to represent different aspects regarding linguistics are obvious. This is particularly the case of the fully faceted major classes, Class 811 Languages, 821 Literature of individual languages and Class 94 History, some of the fully faceted major classes of the scheme (Slavic 2004). These classes allow for unrestricted number of combinations when used in indexing, but only a few examples are mentioned in the schedules. For such classes 
the best implementing solution is the use of pre-combined UDC numbers and, by means of specially written programs, decompose them into their constituents by means of algorithms extracted from the UDC syntax (Riesthuis 1997). This way, post-coordinate searching by words derived from classification is possible on condition of strict agreement with the UDC rules of subdivision and syntax (see also the example in Section 2).

As far as the UDC syntax is concerned there are rules specifying the order in which different types of common auxiliaries should be mentioned in a complex notation. The recommended sequence is: time, ethnic grouping, place, form, language. Nevertheless, this order can become flexible and in line with the indexing policy of each library and is valuable in the correct filing of the UDC notations for browsing purposes from general to specific. Another important requirement with complex notations is the identification of each element contributing to the structure of this number. The compliance to the rules of building such numbers along with the facet indicators for each part of the pre-combined UDC number contribute to the correct treatment of classification data in the system and the appropriate display of their equivalents in the subject index.

According to Slavic (2004) the UDC can manage, in practice, unlimited possibilities of synthesis at different levels:

1. among two or more main class numbers, using symbols that express the relations between two subjects;

2. among main class numbers and one or more common auxiliaries;

3. among main class and one or more special auxiliary numbers;

4. among one or more common auxiliary numbers;

5. among one or more special auxiliary numbers;

6. between UDC main numbers and some other external vocabulary;

7. between UDC main numbers and any other alphabetical extension used for further specification.

A new application of the UDC Online (http://www.udc-hub.com/en/login.php), the complete standard edition of the UDC tables available on the web, offers help in parsing and validation of the complex UDC notations. The software described by Piros (2015) is used to assist the future library systems to analyze UDC complex numbers. An example is given below in two display formats selected by the user. The condition for the searcher is to give in elements such as: UDC number, year of publication of the UDC edition and the description of the UDC number in the selected language, then the result of the analysis can be displayed

in XML format:

<ns:udc_concept xmlns:ns="http://library.inf.unideb.edu/udc/xml" xmlns:xsi="http://www.w3.org/2001/

XMLSchema-instance" udc_edition="2015" notation="821.135.1.09">

$<$ ns:description xml:lang="EN">History of Romanian literature $</ n s:$ description $>$

$<$ ns:main_table_number number1="821.135.1">

$<$ ns:special_auxiliary xsi:type="ns:special_auxiliary_number_pointnought" number1=".09"/>

$</$ ns:main_table_number $>$

$</$ ns:udc_concept $>$

in KWOC format:

\section{Concept:}

821.135.1.09

UDC edition:

2015

Description(s):

History of Romanian literature (EN)

KWOC-index:

Notation URI

821.135.1 http://udcdata.info/067943 
The link provided in the second display connects this result with UDC Summary Link Data, an open source product released under a Creative Commons Attribution Share Alike 3.0 license.

We have seen so far examples of synthesis enumerated at numbers 2 to 5 in the upper-mentioned list. Non-UDC notations and alphabetical extension are highly rated resources of improved specificity in the UDC tables. To mention only one very used example, Class 929 Biographical studies has a large variety of combinations available. Facets are also present in these examples taken from UDC Online:
929:2-36
929:272-732.2
929:75-051
929:94(44)-057.341CHA5
Saints' lives. Hagiography
Biographies of popes
Biographies of painters
929GRO
Biographies of King Charles V of France
Biographies of Hugo Grotius (Huig de Groot)

From The European Library, Freire (2015) describes the challenge of this institution in making subject authority data from library catalogues available in a semantic web as Linked Open Data. The UDC, he argues, has very good LOD data available from standardization viewpoint, but lacks linking to other LOD datasets. Shortcomings, according to Freire, result from the diversity of languages and knowledge organization systems, but also from the heterogeneous levels of detail in subject information. Should the details in classification data be normalized at a lower level, the pre -combined UDC numbers could be minimized, so that more than one record could be linked to each of them. A solution, he argues, would be linking the UDC datasets to Dbpedia.

\section{Further applications}

Today's library users want fast retrieval of most relevant information without much regard for information retrieval proficiency. An interface for mobile devices is a convenient answer to their demands. Search results can be filtered in different ways by altering the first with a subsequent one, according to the user's need. The bibliographic record displayed on a smartphone screen treats the search query just like a library catalogue (Figure 6).

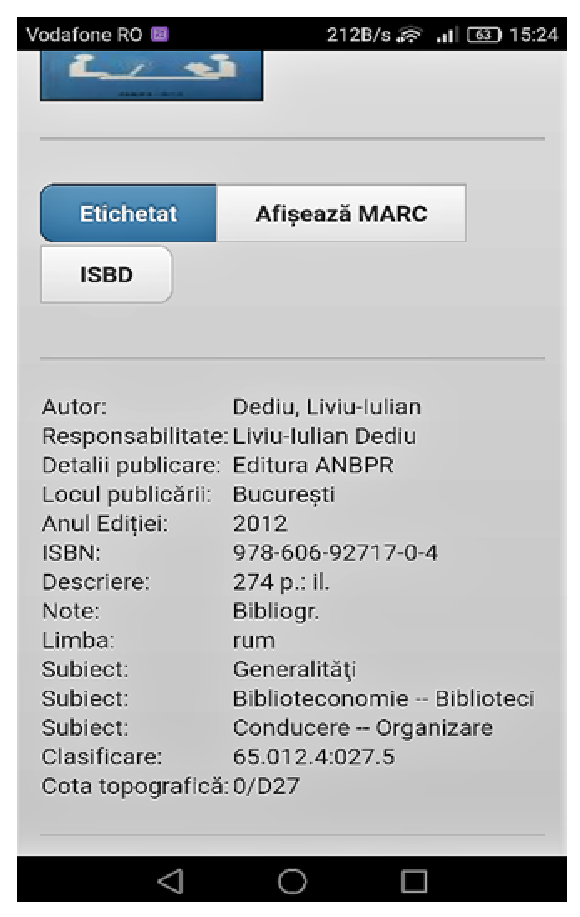

Figure 6. Smartphone application 


\section{Conclusions}

Facets, parsing by facet indicators, expressiveness, flexibility, richness of vocabulary elements hence enlarged subject access points, meaningful sequences giving specificity to the main class number, authority files for mapping classification notation with subject headings, consistency and ease of use for indexers hence improved information retrieval, adapting search routines to the ever demanding user requirements, modern applications i.e. an interface for mobile devices were presented here from the point of view of adjusting the subject approach to information included in library catalogues as appropriate as possible to the new information user needs.

One might argue that additional subject information like language, form of presentation or material, that do not necessarily belong to the topical subject itself can be placed in other fields of a bibliographic record and not in the subject fields. However, when you include this kind of information in a subject field/subfield they are likely to be used for expanding the search space and the result can often be better than the initial one. The larger the variety of subjects retrieved, the more likely to exist at least one of the set of retrieved documents relevant for the formulated query. Reliability of systematic catalogues is beyond any doubt, so their assessment is necessary and is worth any effort demanded for including them in the information sources for the forthcoming society.

\section{Note}

The paper was presented at IFLA/LAC Satelite Meeting, held at Universitatea de Vest, Timișoara, August 15-16, 2017.

\section{References}

Berwick Sayers, W.C. (1957) Foreword, in Ranganathan, S.R. Prolegomena to Library Classification, $2^{\text {nd }}$ ed., London: Library Association.

Drake, M. A. (2003) Encyclopedia of Library and Information Science, $2^{\text {nd }}$ ed., vol. 4, New York, NY and Basel: Marcel Dekker.

Ducheyne, Steffen (2009) To treat of the world: Paul Otlet's ontology and epistemology and the circle of knowledge, Journal of Documentation, 65(2) pp. 223-244, available: http:// dx.doi.org/10.1108/00220410910937598 [accessed 15 March 2017].

Freire, N. (2015) Library linked data: contributions and role of linked subject data, in Slavic, A. and Cordeiro, M.I. (eds.) Classification \& Authority Control: Expanding Resource Discovery: Proceedings of the International UDC Seminar 29-30 October 2015 Lisbon, Portugal, Würzburg: Ergon, pp. 33-36.

Frâncu, V. and Dediu, L.I. (2015) TinREAD - an integrative solution for subject authority control, in Slavic, A. and Cordeiro, M.I. (eds.) Classification \& Authority Control: Expanding Resource Discovery: Proceedings of the International UDC Seminar 29-30 October 2015 Lisbon, Portugal, Würzburg: Ergon, pp. 123-133.

Freeman, R.R. and Atherton, P. (1968) File organization and search strategy using UDC in mechanized reference retrieval systems, in Samuelson, K. (ed.) Mechanized Information Storage, Retrieval and Dissemination: proceedings of the FID/IFIP Joint Conference, Rome, June 14-17, 1967, Amsterdam: North-Holland Publishing, pp. 122-159.

Hug, H. and Noethiger, R. (1991) Ethics (ETH Library Information Control System), in Proceedings of the IATUL Conferences, Paper 22, Cambridge Massachusetts 8-12 July 1991, available: https://docs.lib.purdue.edu/iatul/1991/papers/22/ [accessed 25 March 2017].

Möller, G., Carstensen, K.-U., Diekmann, B. and Wätjen, H. (1999) Automatic classification of 
the World Wide Web using Universal Decimal Classification, in McKenna, B. (ed.) 23rd International Online Information meeting, London, 7-9 December 1999, Oxford: Learned Information Europe, pp. 231-237.

Piros, A. (2015) Automatic interpretation of complex UDC numbers: towards support for library systems, in Slavic, A. and Cordeiro, M.I. (eds.) Classification \& Authority Control: Expanding Resource Discovery: Proceedings of the International UDC Seminar 29-30 October 2015 Lisbon, Portugal, Würzburg: Ergon, pp. 177-193.

Ranganathan, S. R. (1965) The Colon Classification. Rutgers: The State University, Graduate School of Library Science.

Riesthuis, G.J.A. (1997) Decomposition of complex UDC notations, in Knowledge organization for information retrieval: proceedings of the Sixth International Study Conference on Classification Research, London, 16-18 June 1997, The Hague: International Federation for Information and Documentation (FID), pp. 139-143.

Slavic, A. (2004) UDC implementation: from library shelves to a structured indexing language, International Cataloguing and Bibliographic Control, 33(3) pp. 60-65, available: http:// hdl.handle.net/10150/105685 [accessed 20 March 2017].

Vlădescu, G. (1965) Tehnica Clasificării Colon [The Colon Classification's Technique], in Studia bibliologica, Bucureşti: Facultatea de Filologie, Secţia de Biblioteconomie, pp. 133-222. 